\title{
Osteolytic lesion of the tibial shaft in a young boy
}

\author{
Abhishek Vaish (1) ,' Muddassir Siddiqui, ${ }^{1}$ Raju Vaishya, ${ }^{2}$ Pankaj Baweja ${ }^{3}$
}

${ }^{1}$ Orthopedics, Indraprastha Apollo Hospital, New Delhi, India

${ }^{2}$ Orthopaedic and Joint Replacement Surgery, Indraprastha Apollo Hospitals, New Delhi, India

${ }^{3}$ Pathology, Indraprastha Apollo Hospital, New Delhi, India

\section{Correspondence to} Dr Abhishek Vaish; drabhishekvaish@gmail.com

Accepted 26 January 2020

\section{DESCRIPTION}

A 5 -year-old boy presented with swelling and pain over his right leg for 2 months. The pain was diffuse and dull aching, which aggravated on walking and was relieved on taking rest. There were no diurnal variations in its pattern nor did it radiate. This was associated with a diffuse ill-defined swelling over the shaft of the right leg. It was not tender,nonadherent to the underlying structures and was not associated with overlying skin changes. General examination revealed no abnormalities.

A plain X-ray of the right leg showed a large osteolytic lesion in the shaft of the tibia (figure 1A) which was well defined. The margins were sclerosed, but there was no associated periosteal reaction or soft tissue changes. MRI confirmed the presence of the osteolytic lesion, which was hyperintense on T2-weighted images (figure 1B), but there was no breach in the continuity of the cortices and soft tissue extension.

A mini-open biopsy was performed, first. Macroscopically, the tissue was greyish white in colour and soft to firm in its consistency. Microscopically, there were numerous fragments of woven bone in the hypocellular and fibroblastic stroma (figure 2A). Prominent osteoblastic rimming was seen. No significant atypia, mitotic figures or pleomorphismwere seen. These findings were suggestive of osteofibrous dysplasia.

At a second-stage procedure after 2 weeks, a cortical window was created in the anterior tibial shaft and thorough curettage with chemical cauterisation (using 10\% phenol) was performed. ${ }^{1}$ The cavity was filled with morselised allografts mixed with bone marrow aspirate harvested from the patient's iliac crest. Partial weightbearing was allowed initially which was converted to full weightbearing in 3 weeks. Follow-up showed good

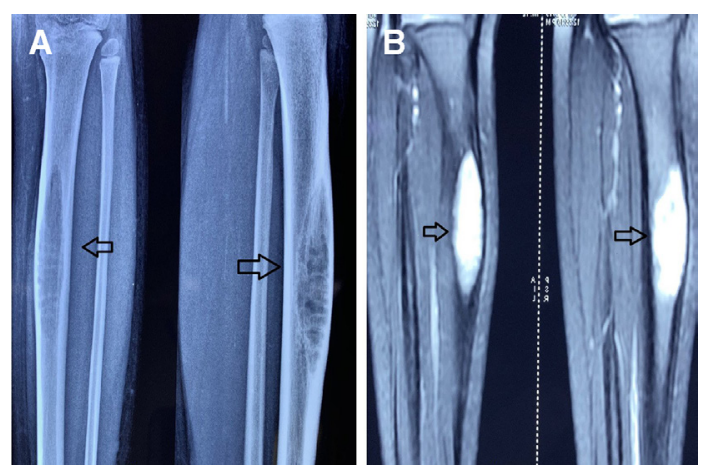

Figure 1 (A) Anteroposterior and lateral view of plain X-ray showing a large osteolytic lesion in tibial shaft. (B) T2-weighted image of MRI showing hyperintensity in the tibial cavity.

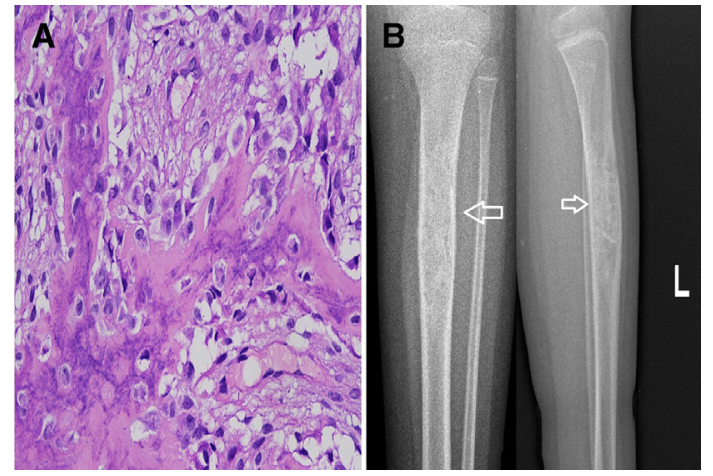

Figure 2 (A) Microscopic view of fragments of woven bone in the hypocellular and fibroblastic stroma. (B) Anteroposterior and lateral view of plain X-ray at 2 years follow-up showing good integration and healing in the cavity.

healing without the reappearance of symptoms at 2 years (figure $2 \mathrm{~B}$ ).

The various differentials of osteolytic lesions with sclerosis were considered including fibrous dysplasia, eosinophilic granuloma, enchondroma, non-ossifying fibroma, osteoblastoma, chondroblastoma and chondromyxoid fibroma. The radiographic findings and the patient's age were indicative of the provisional diagnosis of a benign bone tumour. The size and location of this tumour were rather unusual.

Osteofibrous dysplasia may be treated surgically with marginal resection with or without bone grafting, depending on the size of the lesion and the

\section{Patient's perspective}

My child was in pain for 2 months and could not do the activities of his daily living and sports. We were shocked to find out that there was a large tumour in his leg bone. I was happy and relieved that timely diagnosis and treatment were done and he is doing fine now.

\section{Learning points}

- Osteolytic lesions in children are common and the majority tend to be benign.

- Age of the patient and site of the lesion hold importance in narrowing down the clinical diagnosis.

- The use of allografts is a good option in paediatric patients to fill the cavity. Its integration can be enhanced with the use of bone marrow aspirate injection. 
extent of bony involvement. However, due to the high rate of recurrence this procedure in skeletally immature individuals, the surgery in asymptomatic lesions may be postponed until skeletal maturity, ${ }^{2}$ but there is no contraindication to surgery in symptomatic lesions in children. ${ }^{3}$

Osteofibrous dysplasia is a non-neoplastic condition, which is rare and commonly affects the long bones especially tibia and fibula. It is mostly asymptomatic. ${ }^{4}$ Campanacci and Laus were the first to coin the term osteofibrous dysplasia ${ }^{5}$ and proposed this term to replace ossifying fibroma because of its probable congenital origin, histologic similarity to fibrous dysplasia, and the favoured involvement of the tibia and fibula bones. ${ }^{6}$ Most of these lesions affect the cortex of the tibia, predominantly the middle third of the diaphysis.

Contributors $\mathrm{AV}$ : involved in preparartion, editing and submission of the manuscript; MS: involved in researching, writing and managing the manuscript; RV: involved in operating on the patient, editing the manuscript and sharing the relevant images; PB: involved in providing the pathological analysis and slides for the manuscript.
Funding The authors have not declared a specific grant for this research from any funding agency in the public, commercial or not-for-profit sectors.

Competing interests None declared.

Patient consent for publication Parental/guardian consent obtained.

Provenance and peer review Not commissioned; externally peer reviewed.

ORCID iD

Abhishek Vaish http://orcid.org/0000-0001-7347-0917

\section{REFERENCES}

1 Dürr HR, Maier M, Jansson V, et al. Phenol as an adjuvant for local control in the treatment of giant cell tumour of the bone. Eur J Surg Oncol 1999;25:610-8.

2 Westacott D, Kannu P, Stimec J, et al. Osteofibrous dysplasia of the tibia in children: outcome without resection. J Pediatr Orthop 2019;39:e614-21.

3 Moretti VM, Slotcavage RL, Crawford EA, et al. Curettage and graft alleviates athleticlimiting pain in benign lytic bone lesions. Clin Orthop Relat Res 2011;469:283-8.

4 McCaffrey M, Letts M, Carpenter B, et al. Osteofibrous dysplasia: a review of the literature and presentation of an additional 3 cases. Am J Orthop 2003;32:479-86.

5 Campanacci M, Laus M. Osteofibrous dysplasia of the tibia and fibula. J Bone Joint Surg Am 1981;63:367-75.

6 Campanacci M. Osteofibrous dysplasia of long bones a new clinical entity. Ital J Orthop Traumatol 1976:2:221-37.

Copyright 2020 BMJ Publishing Group. All rights reserved. For permission to reuse any of this content visit

https://www.bmj.com/company/products-services/rights-and-licensing/permissions/

BMJ Case Report Fellows may re-use this article for personal use and teaching without any further permission.

Become a Fellow of BMJ Case Reports today and you can:

- Submit as many cases as you like

- Enjoy fast sympathetic peer review and rapid publication of accepted articles

- Access all the published articles

- Re-use any of the published material for personal use and teaching without further permission

Customer Service

If you have any further queries about your subscription, please contact our customer services team on +44 (0) 2071111105 or via email at support@bmj.com.

Visit casereports.bmj.com for more articles like this and to become a Fellow 